DOI : https://doi.org/10.24843/JFU.2020.v09.i02.p04

pISSN: 2301-7716; eISSN: 2622-4607

Jurnal Farmasi Udayana, Vol 9, No 2, Tahun 2020, 91-99

\title{
Efek Antineuroinflamasi Ekstrak Etanol 96\% Daun Marsilea crenata Presl. Budidaya pada Sel Mikroglia HMC3
}

\author{
Ma'arif, B. ${ }^{1 *}$, Suleman, H.F. ${ }^{1}$, Annisa,R. ${ }^{1}$, Dianti, M.R. ${ }^{1}$, Laswati, H. ${ }^{2}$, Agil, M. ${ }^{3}$ \\ ${ }^{1}$ Jurusan Farmasi, Fakultas Kedokteran dan Ilmu Kesehatan, Universitas Islam Negeri Maulana Malik \\ Ibrahim, Malang,65151 \\ ${ }^{2}$ Departemen Ilmu Kedokteran Fisik dan Rehabilitasi, Fakultas Kedokteran, Universitas Airlangga, \\ Surabaya, 60132 \\ ${ }^{3}$ Departemen Farmakognosi dan Fitokimia, Fakultas Farmasi, Universitas Airlangga, Surabaya, 60115 \\ E-mail: burhan.maarif@farmasi-uin.malang.ac.id
}

Riwayat artikel: Dikirim: 19/07/2020; Diterima: 25/08/2020, Diterbitkan: 27/12/2020

\begin{abstract}
Neuroinflamation is a neurodegenerative disease caused by estrogen deficiency. Marsilea crenata Presl. is a plant that contains phytoestrogens, which are compounds that can replace the function of estrogen in maintaining cell homeostasis in the brain. The purpose of this study was to predict the antineuroinflammatory effect of $96 \%$ ethanol extract of cultivated Marsilea crenata Presl. leaves in HMC3 microglia cells through activated ER measurements, and observed using the immunocytochemistry method. IFN $\gamma$ is induced into cells 24 hours before treatment to cause an inflammatory condition. 96\% ethanol extract of cultivated Marsilea crenata Presl. leaves is given at a dose of $62.5 ; 125$; and $250 \mu \mathrm{g} / \mathrm{ml}$. Genistein $50 \mu \mathrm{m}$ was used as a positive control. The results showed that $96 \%$ ethanol extract of cultivated Marsilea crenata Presl. leaves at doses of 125 and $250 \mu \mathrm{g} / \mathrm{ml}$ can decrease free ER $\beta$ expression with values of 814,216 and 573,190 AU at $\mathrm{p}<0.05$, and shows an increase in the amount of activated ER $\beta$. From these results it can be concluded that the $96 \%$ ethanol extract of cultivated Marsilea crenata Presl. leaves provides a potential antineuroinflammatory effect shown by the decreasing of free ER $\beta$ expression on HMC3 microglia cells with $250 \mu \mathrm{g} / \mathrm{ml}$ as the best dose.
\end{abstract}

Keywords: antineuroinflammation; ER $\beta$; phytoestrogens; Marsilea crenata Pres1.; HMC3 microglia cells

\begin{abstract}
ABSTRAK
Neuroinflamasi merupakan penyakit neurodegeneratif yang disebabkan defisiensi estrogen. Marsilea crenata Presl. merupakan tumbuhan yang mengandung fitoestrogen, yaitu senyawa yang dapat menggantikan fungsi estrogen dalam menjaga homeostasis sel di dalam otak. Tujuan penelitian ini adalah untuk memprediksi efek antineuroinflamasi dari ekstrak etanol 96\% daun Marsilea crenata Presl. budidaya pada sel mikroglia HMC3 melalui pengukuran ER teraktivasi, dan diamati menggunakan metode immunocytochemistry. IFN $\gamma$ diinduksikan ke dalam sel 24 jam sebelum perlakuan untuk menimbulkan kondisi inflamasi. Ekstrak etanol 96\% daun Marsilea crenata Presl. budidaya diberikan dengan dosis 62.5; 125; dan $250 \mu \mathrm{g} / \mathrm{ml}$. Genistein 50 $\mu \mathrm{m}$ digunakan sebagai kontrol positif. Hasil menunjukkan bahwa ekstrak etanol 96\% daun Marsilea crenata Presl. budidaya dengan dosis 125 dan $250 \mu \mathrm{g} / \mathrm{ml}$ dapat menurunkan ekspresi ER $\beta$ bebas dengan nilai 814.216 dan 573.190 AU pada $\mathrm{p}<0.05$, serta menunjukkan peningkatan jumlah ER $\beta$ teraktivasi. Dari hasil ini dapat disimpulkan bahwa ekstrak etanol 96\% daun Marsilea crenata Presl. budidaya memberikan efek antineuroinflamasi yang potensial ditunjukkan dengan penurunan ekspresi ER $\beta$ bebas pada sel mikroglia HMC3 dengan $250 \mu \mathrm{g} / \mathrm{ml}$ sebagai dosis terbaik.
\end{abstract}

Kata kunci: antineuroinflamasi, ER $\beta$, fitoestrogen, Marsilea crenata Presl., sel mikroglia HMC3 


\section{PENDAHULUAN}

Defisiensi estrogen pada wanita pascamenopause dapat menyebabkan ketidakseimbangan hormon, sehingga memicu terjadinya penyakit neurodegeneratif (Rettberg et al., 2014; Varshney dan Nalvarte, 2017; Yang et al., 2012). Neurodegeneratif merupakan suatu keadaan patologis yang dialami oleh seseorang secara progresif, ditandai dengan berkurangnya kemampuan kognitif dan memori karena hilangnya kemampuan fisiologis sel pada sistem saraf (Kovacs, 2014). Sel mikroglia menyebabkan berbagai macam kelainan neurologi pada Sistem Saraf Pusat (SSP), termasuk terbentuknya penyakit. Peningkatan aktivitas sel mikroglia dapat menyebabkan neuroinflamasi kronis pada SSP serta menyebabkan kerusakan SSP secara progresif (Chamniansawat dan Chongthammakun, 2015; Jantaratnotai et al., 2013).

Neuroinflamasi dapat terjadi karena defisiensi estrogen yang dialami wanita pascamenopause (Whitney et al., 2009; Lee et $a l .$, 2013). Gangguan kognitif pada otak seperti neuroinflamasi dapat diatasi dengan penggunaan obat neuroinflamasi seperti Terapi Sulih Hormon (TSH) (Beral, 2003), dimana penggunaannya dalam jangka panjang dapat menimbulkan efek samping yang potensial seperti coronary event, venous thromboembolism, stroke, kanker payudara, dan demensia. Penggunaan TSH akhirnya menjadi perdebatan sehingga dianggap perlu dilakukan penggantian terapi yang dinilai lebih aman dengan efikasi yang hampir sama (Agil et al., 2019; Jantaratnotai et al., 2013; Lee et al., 2013; Sirotkin dan Harrath, 2014).

Fitoestrogen dapat digunakan sebagai sumber pengobatan alternatif untuk defisiensi estrogen, terutama pada otak untuk meningkatkan fungsi kognitif (Alldredge et al., 2013; Jantaratnotai et al., 2013; Villa et al., 2016). Fitoestrogen adalah kelompok senyawa yang memiliki struktur atau fungsi menyerupai estrogen, dan dapat menggantikan fungsi estrogen dalam tubuh (Cui et al., 2013; Villiers et al., 2009; Cos et al., 2003 ; Yang et al., 2012). Salah satu sumber fitoestrogen yang diketahui yaitu dari tanaman Marsilea crenata Presl. (Michel et al., 2013).

Marsilea crenata Presl. adalah tanaman unik yang tumbuh daerah di Jawa Timur, Indonesia. Daun Marsilea crenata Presl. banyak digunakan sebagai bahan untuk makanan tradisional (Afriastini, 2003; Akbar et al., 2014; Nurjanah et al., 2012). Marsilea crenata Presl. memiliki potensi untuk menyeimbangkan jumlah estrogen dalam tubuh, salah satunya yang di budidaya di Daerah Pagu, Kediri, Jawa Timur (Ma'arif et al., 2018; Trisunuwati, 2017). Beberapa penelitian menunjukkan bahwa ekstrak etanol 96\% daun Marsilea crenata Presl. mengandung zat-zat yang menyerupai estrogen dalam konsentrasi tinggi (Laswati, 2011), dan memiliki aktivitas karena kemampuannya untuk mempengaruhi fungsi estrogen (Laswati, 2011; Ma'arif et al., 2011; Ma'arif et al., 2018). Studi lain juga menunjukkan bahwa Marsilea crenata Presl. memiliki aktifitas antiosteoporosis yang disebabkan oleh senyawa fitoestrogen di dalamnya (Agil et al., 2019; Laswati, 2011; Ma'arif et al., 2018).

Penelitian ini bertujuan mengamati kemampuan fitoestrogen dalam ekstrak etanol 96\% daun Marsilea crenata Presl. budidaya untuk berikatan dengan Estrogen Receptor- $\beta$ $(\mathrm{ER} \beta)$ pada sel mikroglia HMC3. Hasil dari ikatan yang terjadi, akan mengurangi aktivitas mikroglia sehingga neuroinflamasi dapat diturunkan. Pemberian Interferon Gamma (IFN $\gamma)$ terhadap sel dilakukan untuk menimbulkan proses patofisiologi neuroinflamasi dalam bentuk inflamasi yang diperpanjang, kemudian dihambat dengan menginduksi sel menggunakan ekstrak etanol 96\% daun Marsilea crenata Presl. budidaya. Dalam penelitian ini digunakan Marsilea crenata Presl. yang dibudidaya, karena pada tanaman budidaya dihasilkan spesies yang lebih unggul dari segi kandungannya dan lebih seragam, serta diperoleh tanaman dengan hasil maksimal dari segi kualitas maupun kuantitasnya (Ulukan, 2009; Chen et al., 2016). Hal ini dipengaruhi oleh beberapa faktor seperti nutrisi, tanah dan pengairan, serta faktor lingkungan (Sher et al., 2010). 
Efek antineuroinflamasi ditunjukkan melalui pengukuran ER $\beta$ bebas untuk memastikan proses jalur ER-dependent (Ma'arif et al., 2019a). Mekanisme tersebut dapat menjadi langkah awal pengembangan produk antineuroinflamasi dari daun Marsilea crenata Presl. budidaya.

\section{BAHAN DAN METODE}

\subsection{Bahan}

\subsubsection{Bahan Tanaman}

Daun Marsilea crenata Presl yang dipanen dari Daerah Pagu, Kediri, Jawa Timur, Indonesia pada bulan September 2019, dan diidentifikasi di UPT Materia Medica, Batu, Indonesia pada bulan September 2019 dengan kunci determinasinya 1a-17b-18a-1. Daun dikeringkan dan digiling untuk mempertahankan warna hijau.

\subsubsection{Bahan kimia}

Pelarut etanol 96\%, fetal bovine serum (FBS), penisilin-streptomisin, Eagle's Minimum Essential Medium (EMEM), dimethyl sulfoxide (DMSO), tween 80, phosphate buffer saline (PBS), genistein, Paraformaldehida (PFA), dan reagen lainnya yang didapat dari Laboratorium Sentral Ilmu Hayati (LSIH), Universitas Brawijaya, Malang, Indonesia.

\subsection{Alat}

Alat yang digunakan dalam proses preparasi dan ekstraksi Marsilea crenata Presl. diantaranya adalah moisture analyzer (Mettler Toledo HC-103), ultrasonicbath (Soltec Sonica 5300 EP S3), universal oven (Memmert UN 55) dan rotary evaporator (Heidolph Hei VAP ML/G3). Alat yang digunakan untuk kultur sel dan uji aktivitas adalah mikropipet $1000 \mu \mathrm{l}$, conical tube $15 \mathrm{ml}$ dan $50 \mathrm{ml}$, flask culture 15 $\mathrm{ml}$, milipore 0,22 $\mu \mathrm{m}$, spuit $10 \mathrm{ml}$, scrapper, microplate 24 well. Selain itu dibutuhkan instrumen seperti inkubator (Thermo Scientific Hera Cell 150i CO2), bio safety cabinet (Thermo Scientific Hera Safe KS Class II), inverted microscope (Olympus IX 71), waterbath (Thermo Scientific Aquabath 18022AQ), centrifuge (LW C5), mikroskop inverted
Olympus tipe CX23 dan Confocal Laser Scanning Microscopy (CLSM) fluoview Olympus tipe FV1000.

\subsection{Metode \\ 2.3.1 Kultur sel}

Sel mikroglia HMC3 didapatkan dari American Type Culture Collection (ATCC). Sel dikultur didalam flask $75 \mathrm{~m}^{2}$, yang mengandung $10 \%$ FBS, $1 \%$ penstrep, medium komplit EMEM $\pm 5 \mathrm{ml}$. Kemudian dimasukan kedalam inkubator $\mathrm{CO}_{2} 5 \%$ pada suhu $37^{\circ} \mathrm{C}$. Sel diinkubasi \pm 7 hari.

\subsubsection{Prosedur ekstraksi}

Proses ekstraksi dilakukan menggunakan metode Ultrasonic Asisted Extraction (UAE). Ditimbang 30 gram serbuk simplisia daun Marsilea crenata Presl budidaya, ditambahkan $500 \mathrm{ml}$ etanol 96\%, diekstraksi dengan ultrasonic bath Soltec selama $3 \times 2$ menit. Kemudian disaring dan filtrat diuapkan dengan rotary evaporator Heidolph G3.

\subsubsection{Preparasi uji sampel}

IFN $\gamma$ diinduksikan setelah kultur sel dilakukan dalam microplate 24 well dan mencapai konfluensi sebanyak 80\%. Setelah diinduksi dengan IFN $\gamma$ selama 24 jam, sel dibilas dengan PBS lalu diberi perlakuan menggunakan sampel. Sampel disiapkan dengan menimbang ekstrak etanol $96 \%$ sebanyak $50 \mathrm{mg}$ dan dicampur dengan DMSO $0.5 \%$ dan Tween 80 $0.5 \%$, kemudian disuspensikan untuk menghasilkan larutan baku induk $5000 \mu \mathrm{g} / \mathrm{ml}$. Selanjutnya sampel disaring menggunakan mikrofilter $0.22 \mu \mathrm{l}$ dan diencerkan untuk menghasilkan konsentrasi akhir 62.5; 125; dan $250 \mu \mathrm{g} / \mathrm{ml}$. Larutan sampel kemudian diinduksikan ke dalam microplate 24 well yang mengandung sel mikroglia HMC3 selama 48 jam. Sel kemudian difiksasi dengan PFA 4\%, ditambahkan Triton X-100 dan blocking buffer serta antibodi primer dan antibodi sekunder (anti-rabbit FITC). Kemudian, dibilas dengan PBS dan divisualisasikan ER $\beta$ dengan CLSM dan menggunakan software Olympus Fluoview Ver. 4.2a. pada panjang gelombang $488 \mathrm{~nm}$ (Engler-Chiurazzi et al., 2017). 
DOI : https://doi.org/10.24843/JFU.2020.v09.i02.p04

pISSN: 2301-7716; eISSN: 2622-4607

Jurnal Farmasi Udayana, Vol 9, No 2, Tahun 2020, 91-99

\section{HASIL}

Uji aktivitas antineuroinflamasi dilakukan menggunakan metode pewarnaan yaitu immunocytochemistry (ICC) dan divisualisasikan menggunakan instrumen CLSM. Metode ICC memungkinkan untuk mengevaluasi sel-sel dalam sampel tertentu yang dapat menghasilkan fluoresensi antigen yang diinginkan (Taylor dan Rudbeck, 2013). Hasil dari ICC yang divisualisasikan dengan instrumen CLSM dapat dilihat pada Gambar 1 dan Gambar 2.

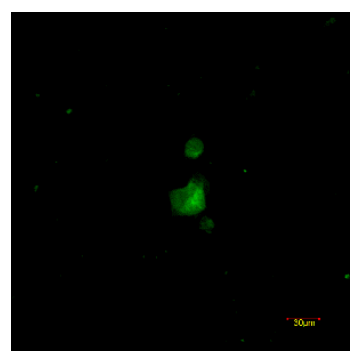

(A)

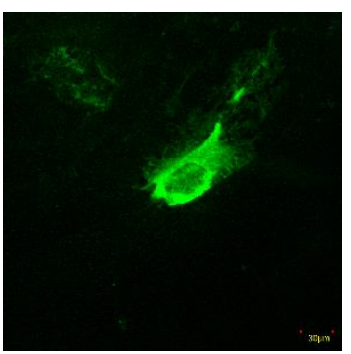

(B)

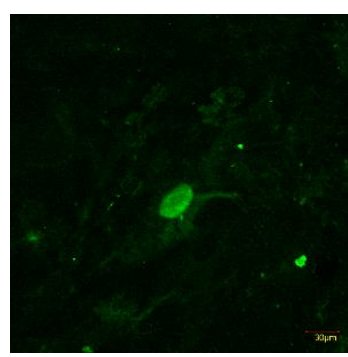

(C)

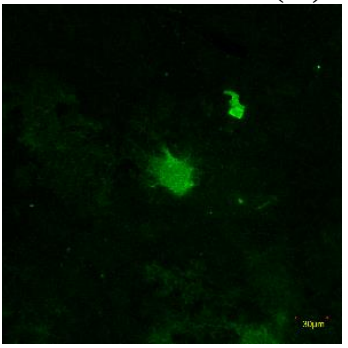

(D)

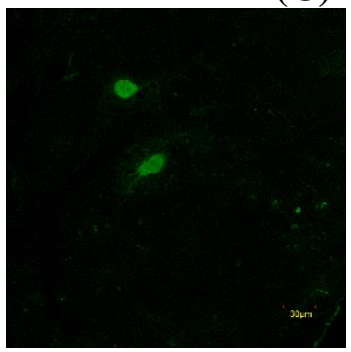

(E)

Gambar 1. Intensitas Fluoresensi ER $\beta$ bebas pada Sel Mikroglia HMC3 (A) Kontrol Negatif (B) $62.5 \mu \mathrm{g} / \mathrm{ml}$ (C) 125 $\mu \mathrm{g} / \mathrm{ml}(\mathrm{D}) 250 \mu \mathrm{g} / \mathrm{ml}(\mathrm{E})$ Kontrol Positif

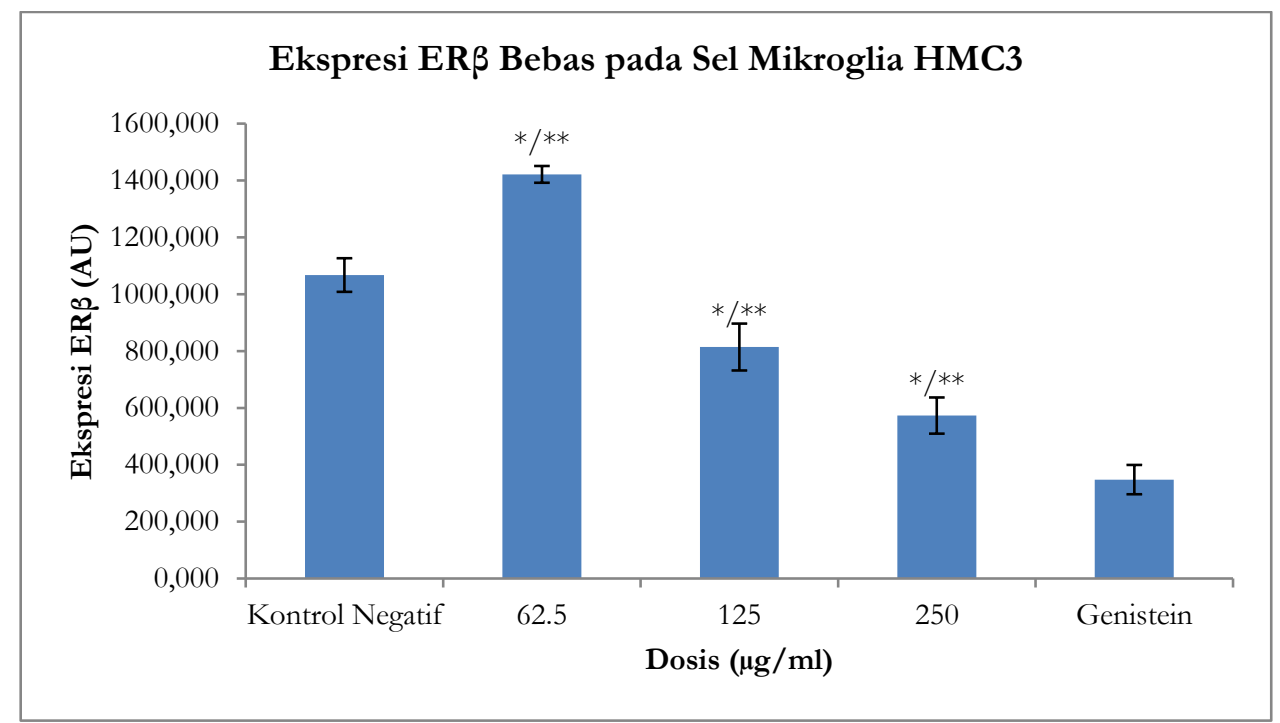

Gambar 2. Ekspresi ER $\beta$ bebas pada sel mikroglia HMC3 setelah pemberian ekstrak etanol 96\% Daun Marsilea crenata Presl. Budidaya. Tanda “*” menunjukkan perbedaan signifikan terhadap kontrol negatif, sedangkan tanda “**” menunjukkan perbedaan signifikan terhadap Genistein. 
Gambar 1 merupakan hasil dari visualisasi menggunakan instrumen CLSM. Hasil pendar tersebut memperlihatkan ekspresi ER $\beta$ bebas dalam bentuk gambar dan angka dengan satuan Arbitrary Unit (AU). Gambar 2 merupakan hasil perbandingan ekspresi ER $\beta$ bebas pada dosis 62.5; 125; dan $250 \mu \mathrm{g} / \mathrm{ml}$ dengan kontrol negatif dan kontrol positif. Semua konsentrasi menunjukkan perbedaan secara signifikan terhadap kontrol negatif $(\mathrm{p}=0,000, \mathrm{p}=0,000$, dan $\mathrm{p}=0,000$ ), dengan nilai ekspresi $\mathrm{ER} \beta$ bebas konsentrasi $62,5 \mu \mathrm{g} / \mathrm{ml}$ lebih tinggi, sedangkan konsentrasi 125 dan $250 \mu \mathrm{g} / \mathrm{ml}$ lebih rendah daripada kontrol negatif. Semua konsentrasi juga menunjukkan perbedaan signifikan terhadap Genistein ( $\mathrm{p}=0,000, \mathrm{p}=0,000$, dan $\mathrm{p}=0,001)$. Konsentrasi $250 \mu \mathrm{g} / \mathrm{ml}$ memberikan hasil terbaik dalam menurunkan ekspresi ER $\beta$ bebas.

\section{PEMBAHASAN}

Kekurangan estrogen dalam tubuh akan menyebabkan ketidakseimbangan aktivitas otak (Tang dan Lee, 2015; Varshney dan Nalvarte, 2017), karena Estrogen Receptor (ER) tidak memperoleh estrogen yang diproduksi oleh tubuh sehingga menyebabkan penurunan jumlah estrogen receptor yang teraktivasi. Penurunan jumlah ER teraktivasi dalam sel-sel sistem saraf pusat menghasilkan peningkatan aktivitas Nuclear Factor kappa-light-chain-enhancer of activated $B$ cells (NF- $\mathrm{kB})$, yang dapat mempengaruhi transkripsi protein, salah satunya berada di sel HMC3 (Villa et al., 2016). NF- $\mathrm{kB}$ merupakan faktor transkripsi yang bertanggung jawab untuk sistem kekebalan tubuh dan respons inflamasi (Kovacs, 2014). Sel mikroglia terlibat dalam proses neuroinflamasi, dimana sel ini teraktivasi pada M1 polarity (pro-inflamasi) melalui jalur klasik (Ma'arif et al., 2019b).

Induksi IFN $\gamma$ berfungsi untuk mengaktifkan sel mikroglia HMC3 yang secara patofisiologis akan memasuki mikroglia melalui Toll Like Receptor 4 (TLR4) sehingga mengaktifkan NF- $\mathrm{NB}$ untuk mendekati inti sel mikroglia karena terjadi pergantian isomer senyawa protein dari monomer menjadi oligomer dan kemudian mempengaruhi sintesis protein sel
(Tang dan Le, 2015; Villa et al., 2016). Sel mikroglia HMC3 yang aktif bersifat proinflamasi (Cherry et al., 2014; Mizuno, 2015).

Gambar 1 menunjukkan fluoresensi ER $\beta$ bebas. ER $\beta$ bebas berikatan dengan antibodi primer saat pewarnaan ICC, sedangkan ER teraktivasi terbentuk dari ikatan ER dan senyawa fitoestrogen yang terkandung dalam ekstrak etanol 96\% daun Marsilea crenata Presl. budidaya. Antibodi akan berikatan dengan ER $\beta$ secara spesifik di area dimana ligan berikatan dengan ER $\beta$. Apabila ER $\beta$ telah berikatan dengan sebuah ligan seperti fitoestrogen dan menjadi teraktivasi, antibodi tidak dapat berikatan dengan ER $\beta$ dikarenakan afinitas fitoestrogen yang lebih besar dibandingkan antibodi ER $\beta$. Hal ini menunjukkan bahwa ER $\beta$ teraktivasi tidak akan berfluoresensi. Semakin sedikit ER $\beta$ bebas artinya semakin banyak ER $\beta$ yang berikatan dengan senyawa fitoestrogen atau ER $\beta$ teraktivasi.

Gambar 2 menjelaskan bahwa pemberian ekstrak etanol 96\% daun Marsilea crenata Presl. budidaya dengan varian dosis mampu menurunkan ekspresi ER $\beta$ bebas. Hal ini menunjukkan bahwa banyak ER yang berikatan dengan senyawa fitoestrogen. Proses berikatan senyawa fitoestrogen dengan reseptornya dapat melalui berbagai mekanisme, salah satunya melalui jalur ER-dependent. Jalur ini memberikan gambaran bahwa senyawa fitoestrogen berikatan dengan ER dalam inti sel seperti ER $\beta$ yang mampu memberikan pengaruh pada faktor transkripsi sel mikroglia (Cui et al., 2013; Vrtačnik et al., 2014), salah satunya NF$\kappa \mathrm{B}$.

Uji Least Significant Differenc (LSD) juga dilakukan untuk mengetahui secara detail signifikansi perbedaan dari data pengukuran intensitas fluoresensi ER $\beta$ tiap dosis perlakuan yang didapat. Hasil uji LSD menunjukan terdapat perbedaan signifikan antara dosis 62.5;125; dan $250 \mu \mathrm{g} / \mathrm{ml}$ dengan kontrol negatif, dengan nilai signifikansi masing-masing yaitu 0.000 ( $\mathrm{p}<0.05$ ), hal tersebut menunjukan bahwa pada semua dosis perlakuan dapat menurunkan ekspresi ER $\beta$ bebas. Hasil uji LSD tersebut dapat menjelaskan bahwa senyawa fitoestrogen dalam 
ekstrak etanol 96\% daun Marsilea crenata Presl. budidaya mampu berikatan dengan reseptor estrogen serta mampu memberikan aktifitas antineuroinflamasi pada sel mikroglia HMC3 dengan nilai effective dose (ED50) sebesar 3.724 $\mu \mathrm{g} / \mathrm{ml}$

Dalam penelitiaan ini produksi $\mathrm{NF}-\kappa \mathrm{B}$ tinggi karena adanya induksi IFN $\gamma$ pada sel mikroglia. Senyawa fitoestrogen dari ekstrak etanol 96\% daun Marsilea crenata Presl. akan melalui proses non klasikal serta melakukan fosforilasi p50 dan p52 NF-kB. Senyawa fitoestrogen tersebut akan meningkatkan ER teraktivasi dan menghambat produksi NF- $\kappa \mathrm{B}$ secara langsung, sehingga ekspresi mediator peradangan penyebab neuroinflamasi dapat mengalami penurunan (Kalaitzidis dan Gilmore, 2005). Ketika mediator inflamasi dalam sel mikroglia telah terkendali, aktivitas sel mikroglia akan mengalami penurunan secara bertahap (Matt dan Johnson, 2016). Hal ini menjelaskan bahwa senyawa fitoestrogen dalam ekstrak etanol 96\% daun Marsilea crenata Presl. budidaya dapat menggantikan fungsi estrogen melalui jalur ER-independent.

Senyawa fitoestrogen pada daun Marsilea crenata Presl. budidaya mampu berikatan dengan reseptor estrogen (ER-dependent pathway) maupun menghambat produksi $\mathrm{NF}-\kappa \mathrm{B}$ (ER-independent pathway). Sehingga, senyawa fitoestrogen pada tanaman tersebut dapat menggantikan peran estrogen yang mengalami penurunan kualitas maupun kuantitasnya untuk memberikan aktivitas pada tubuh (Ji dan Yu, 2015). Kelebihan dari penggunaan Marsilea crenata Presl. budidaya sendiri dapat dilihat dari hasil yang signifikan pada peningkatan ekspresi ER $\beta$ yang teraktivasi dikarenakan spesies yang digunakan lebih unggul dari segi kandungannya dan lebih seragam (Chen et al., 2016). Dengan demikian, senyawa fitoestrogen dalam ekstrak etanol 96\% daun Marsilea crenata Presl. budidaya memiliki respon antineuroinflamasi.

\section{KESIMPULAN}

Ekstrak etanol 96\% daun Marsilea crenata Presl. budidaya memiliki aktivitas antineuroinflamasi ditunjukkan dengan dosis 125 dan $250 \mu \mathrm{g} / \mathrm{ml}$ yang dapat menurunkan ekspresi ER $\beta$ bebas pada sel mikroglia HMC3. Dosis 250 $\mu \mathrm{g} / \mathrm{ml}$ merupakan dosis terbaik dalam menurunkan ekpresi ER $\beta$ bebas dengan nilai intensitas 573.190 AU.

\section{UCAPAN TERIMAKASIH}

Penelitian ini didanai oleh Bantuan Operasional Perguruan Tinggi Negeri (BOPTN) Universitas Islam Negeri Maulana Malik Ibrahim Malang.

\section{DAFTAR PUSTAKA}

1. [ATCC] American Type Culture Collection. 2017. HMC3 (ATCC® CRL-3304 ${ }^{\mathrm{TM}}$ ) American Type Culture Collection. Available from www.atcc.org.

2. Agil, M., Ma'arif, B., Aemi, N.Y., 2019. Aktivitas antiosteoporosis fraksi $n$-Heksana daun Marsilea crenata Presl. dalam meningkatkan kepadatan tulang trabekular vertebra mencit betina. J. Tumbuh. Obat Indonesia 11 , 7. https://doi.org/10.22435/jtoi.v11i2.671

3. Afriastini, J. J. 2003. Marsilea crenata Presl. dalam: de Winter WP, Amoroso VB, editor. Cryptograms: Ferns and fern allies. Bogor : LIPI.

4. Akbar, A.A., Fianto, A.Y.A., Sutikno. 2014. Penciptaan buku referensi masakan semanggi sebagai upaya pelestarian kuliner tradisional Surabaya. Art Nouveau 3, 1.

5. Alldredge,B.K., Corelli, R.L., Ernst, M.E., Guglielmo, B.J., Jacobson, P.A., Kradjan, W.A., Williams, B.R. 2013. Applied Therapeutics. PA : Lippincot Williams Dan Wilkins.

6. Arteaga-Lopez, Paola, Handal-Silva, Anabella y Morán-Perales, José Luis, 2003. Differential cholinergic system regulation of mRNA ex-pression of estrogen receptors in 
the hypothalamus of the female rat. Revista de Ciencias Naturales y Agropecuarias.

7. Beral V., 2003. Breast cancer and hormonereplacement therapy in the million women study. The Lancet 362, 419-427.

8. Chamniansawat, S., Chongthammakun, S., 2015. Inhibition of hippocampal estrogen synthesis by reactive microglia leads to down-regulation of synaptic protein expression. NeuroToxicology 46, 25-34. https://doi.org/10.1016/j.neuro.2014.11.005

9. Chen, S.L., Yu, H., Luo, H.M., Wu, Q., Li, C.F., Steinmetz, A., 2016. Conservation and sustainable use of medicinal plants: problems, progress, and prospects. Chin Med, 11, 37.

10. Cherry J, Olschowka J, O’banion K. 2014. Neuroinflammation and M2 microglia: the good, the bad, and the inflamed. J Neuroinflamm 11, 98.

11. Cos, P., Bruyne, T.D., Apers, S., Berghe, D.V., Pieters, L., Vlietinck, J.A., 2003. Review: Phytoestrogen Recent Developments.

12. Cui, J., Shen, Y., Li, R., 2013. Estrogen synthesis and signaling pathways during aging: from periphery to brain. Trends in Molecular Medicine 19, 197-209. https://doi.org/10.1016/j.molmed.2012.12.0 07

13. Engler-Chiurazzi, E.B., Brown, C.M., Povroznik, J.M., Simpkins, J.W., 2017. Estrogens as neuroprotectants: Estrogenic actions in the context of cognitive aging and brain injury. Progress in Neurobiology 157, 188-211.

https://doi.org/10.1016/j.pneurobio.2015.12 .008

14. Jantaratnotai, N., Utaisincharoen, P., Sanvarinda, P., Thampithak, A., Sanvarinda, Y., 2013. Phytoestrogens mediated antiinflammatory effect through suppression of IRF-1 and pSTAT1 expressions in lipopolysaccharide-activated microglia. International Immunopharmacology 17, 483-488.

https://doi.org/10.1016/j.intimp.2013.07.01 3
15. Ji, M.-X., Yu, Q., 2015. Primary osteoporosis in postmenopausal women. Chronic Diseases and Translational Medicine 1, 9-13. https://doi.org/10.1016/j.cdtm.2015.02.006

16. Kalaitzidis, D., Gilmore, T.D., 2005. Transcription factor cross-talk: the estrogen receptor and NF- $\kappa \mathrm{B}$. Trends in Endocrinology \& Metabolism 16, 46-52. https://doi.org/10.1016/j.tem.2005.01.004

17. Kovacs, G.G., 2014. Current concepts of neurodegenerative diseases. EMJ Neurol 9.

18. Kulkarni, A., Ganesan, P., O'donnel, L.A., 2016. Interferon Gamma: Influence on Neural Stem Cell Function in Neurodegenerative and Neuroinflammatory Disease. Libertas Academica, 9(51).

19. Laswati, H., 2011. Green clover potentiates delaying the increment of imbalance bone remodeling process in postmenopausal women.Folia Medica Indonesiana 47, 112117.

20. Lee, W.-L., Tsui, K.-H., Seow, K.-M., Cheng, M.-H., Su, W.-H., Chen, C.-P., Wang, P.-H., 2013. Hormone therapy for postmenopausal women-An unanswered issue. Gynecology and Minimally Invasive Therapy 2, 13-17. https://doi.org/10.1016/j.gmit.2012.12.003

21. Ma'arif, B., Agil, M., Laswati, H., 2011. X Phytochemical Assessment On n-hexane Extract And Fractions Of Marsilea crenata Presl. Leaves Through GC-MS. Traditional Medicine Journal 2, 77-85.

22. Ma'arif, B., Agil, M., Laswati, H., 2018. Alkaline phosphatase activity of Marsilea crenata Presl. extract and fractions as marker of MC3T3-E1 osteoblast cell differentiation. J App Pharm Sci. https://doi.org/10.7324/JAPS.2018.8308

23. Ma'arif, B., Agil, M., Laswati, H., 2019a. The enhancement of Arg 1 and activated ER $\beta$ expression in microglia HMC3 by induction of $96 \%$ ethanol extract of Marsilea crenata Presl. leaves. Journal of Basic and Clinical Physiology and Pharmacology 30. https://doi.org/10.1515/jbcpp-2020-0284 
DOI : https://doi.org/10.24843/JFU.2020.v09.i02.p04

pISSN: 2301-7716; eISSN: 2622-4607

Jurnal Farmasi Udayana, Vol 9, No 2, Tahun 2020, 91-99

24. Ma'arif B, Mirza DM, Hasanah M, Laswati H, Agil M. 2019b. Antineuroinflammation activity of n-butanol fraction of Marsilea crenata Presl. in microglia HMC3 cell line. Journal of Basic and Clinical Physiology and Pharmacology.

25. Matt, S.M., Johnson, R.W., 2016. Neuroimmune dysfunction during brain aging: new insights in microglial cell regulation. Current Opinion in Pharmacology 26, 96101.

https://doi.org/10.1016/j.coph.2015.10.009

26. Michel, T., Halabalaki, M., Skaltsounis, A.L., 2013. New concepts, experimental approaches, and dereplication strategies for the discovery of novel phytoestrogens from natural sources. Planta Med 79, 514-532. https://doi.org/10.1055/s-0032-1328300

27. Mizuno T. 2015. Neuron-microglia interaction in neuroinflammation. Clin Exp Neuroimmunol 6: 225-31.

28. Nurjanah, Aulia, A., Abdullah, A., 2012. Aktivitas antioksidan dan komponen bioaktif semanggi air (Marsilea crenata). Jurnal Inovasi dan Kewirausahaan 1, 7.

29. Patro, I., Nagayach, A., Sinha, S., Patro, N., 2016. Inflammation: the Common Link in Brain Pathologies. Singapore : Springer Science and Business Media.

30. Rettberg, J.R., Yao, J., Brinton, R.D., 2014. Estrogen: A master regulator of bioenergetic systems in the brain and body. Frontiers in Neuroendocrinology $35, \quad 8-30$. https://doi.org/10.1016/j.yfrne.2013.08.001

31. Sher, H., Alyemeni, M.N., Faridullah, 2010. Cultivation and domestication study of high value medicinal plant species (its economic potential and linkages with commercialization). African Journal of Agricultural Research, 5(18), 2462-2470.

32. Sirotkin, A.V., Harrath, A.H., 2014. Phytoestrogens and their effects. European Journal of Pharmacology 741, 230-236. https://doi.org/10.1016/j.ejphar.2014.07.05 7

33. Tang, Y., Le, W., 2015. Differential Roles of M1 and M2 Microglia in Neurodegenerative
Diseases. New York : Springer Science and Business Media.

34. Taylor, C. R., Rudbeck, L., 2013. Immunohistochemical Staining Methods. Dako Denmark : IHC Handbook.

35. Trisunuwati, P., 2017. Eficacy of water clover extract (Marsilea crenata) against blood estrogen progesteron balance, blood calcium levels and impact on dense of bone tissue of rat (Rattus novergicus). RJLS 4, $50-55$.

https://doi.org/10.21776/ub.rjls.2017.004.0 1.7

36. Ulukan, H., 2009. The evolution of cultivated plant species: classical plant breeding versus genetic engineering. Plant Syst Evol 280, 133-142.

37. Varshney, M., Nalvarte, I., 2017. Genes, Gender, environment, and novel functions of estrogen receptor beta in the susceptibility to neurodevelopmental disorders. Brain Sciences $7, \quad 24$. https://doi.org/10.3390/brainsci7030024

38. Villiers, T.J., 2009. Bone Health and Osteoporosis in Postmenopausal Women. Elsevier: Best Practice \& Research Clinical Obstetrics and Gynaecology 23, 73-85.

39. Villa, A., Vegeto, E., Poletti, A., Maggi, A., 2016. Estrogens, neuroinflammation, and neurodegeneration. Endocrine Reviews 37, 372-402. https://doi.org/10.1210/er.20161007

40. Vrtačnik, P., Ostanek, B., Mencej-Bedrač, S., Marc, J., 2014. The many faces of estrogen signaling. Biochem Med 24, 329342. https://doi.org/10.11613/BM.2014.035

41. Whitney, N.P., Eidem, T.M., Peng, H., Huang, Y., Zheng, J.C., 2009. Inflammation mediates varying effects in neurogenesis: relevance to the pathogenesis of brain injury and neurodegenerative disorders. Journal of Neurochemistry, 108(6), 1343-1359.

42. Yang, T.-S., Wang, S.-Y., Yang, Y.-C., Su, C.-H., Lee, F.-K., Chen, S.-C., Tseng, C.-Y., Jou, H.-J., Huang, J.-P., Huang, K.-E., 2012. Effects of standardized phytoestrogen on Taiwanese menopausal women. Taiwanese Journal of Obstetrics and Gynecology 51, 
DOI : https://doi.org/10.24843/JFU.2020.v09.i02.p04 pISSN: 2301-7716; eISSN: 2622-4607

Jurnal Farmasi Udayana, Vol 9, No 2, Tahun 2020, 91-99

229 235.

https://doi.org/10.1016/j.tjog.2012.04.011 